\title{
Local breeds and pastoral farming on the North Mediterranean shore: a univocal coevolution? An example of dairy sheep farming systems in Corsica (France) and Thessaly (Greece)
}

\author{
Lola Perucho $^{*}$, , Ioannis Hadjigeorgiou ${ }^{b}$, Anne Lauvie ${ }^{c}$, Charles Henri Moulin ${ }^{c}$, Jean \\ Christophe Paoli ${ }^{\mathrm{a}}$ and Christina Ligda ${ }^{\mathrm{d}}$ \\ ${ }^{a}$ INRAE - SELMET-LRDE, Quartier Grossetti, Corte, 20250, France \\ ${ }^{b}$ Department of Nutritional Physiology and Feeding, Faculty of Animal Science, Agricultural University of Athens, 75 Iera \\ Odos, Athens, 11855, Greece \\ ${ }^{c}$ UMR Systèmes d'élevage Méditerranéens et Tropicaux (SELMET), INRAE -CIRAD - MontpellierSupAgro -Univ \\ Montpellier, 2 place Pierre Viala, Montpellier cedex 1, 34060, France \\ ${ }^{d}$ Veterinary Research Institute, Hellenic Agricultural Organization, Thessaloniki, 57001, Greece
}

\begin{abstract}
Using local resources for ruminant feeding is a way to achieve agroecological production in pastoral farming systems. In North Mediterranean countries, sheep farming systems have evolved towards more intensive systems in lowland and hilly areas, whereas remote and rough pastureland is abandoned and local breeds are rarely maintained; rather, they are progressively replaced by highly productive breeds and their crosses. Using the examples of Corsica (France) and Thessaly (Greece), two dairy sheep farming territories developing intensive farming systems that differ in the livestock breeds they use, we explored the hypothesis that the use of local breeds may not be systematically related to the maintenance of pastoral practices in Mediterranean dairy sheep farming systems. For this purpose, three data sets based on interviews with sheep farmers of local breeds and crossbred flocks were analysed in two study areas. The results demonstrated that local breeds' adaptive abilities can be used in crossbred flocks or purebred flocks to maintain a feeding system based on pastoral components. However, other drivers also appear to lead into the declining use of local pastoral resources. Apart from the use of local breeds, year-to-year adjustments of replacement and culling rates sometimes have to be applied in order to address the inter-annual variations of the fodder on offer. This paper provides an original approach to studying the link between local breeds and the pastoral components of farming systems by combining synchronic and diachronic analyses of the practices in crossbred and purebred flocks composed of local breeds.
\end{abstract}

Keywords: Crossbreeding, grazing, breeding practices, Karagouniko sheep breed, Corsican sheep breed

Citation: Perucho, L., Hadjigeorgiou, I., Lauvie, A., Moulin, C. H., Paoli, J. C., Ligda, C. (2021). Local breeds and pastoral farming on the North Mediterranean shore: a univocal coevolution? An example of dairy sheep farming systems in Corsica (France) and Thessaly (Greece). Genetic Resources 2 (4), 7-20. doi: 10.46265/genresj.WUDA2135.

(C) Copyright 2021 the Authors.

This is an open access article distributed under the terms of the Creative Commons Attribution License (CC BY 4.0), which permits unrestricted use, distribution, and reproduction in any medium, provided the original author and source are

credited.

\section{Introduction}

The agroecological transition in livestock farming relies on decreasing farm inputs and increasing the use of

* Corresponding author: Lola Perucho

(lolaperucho88@gmail.com) local feed resources and farm leftovers to meet the needs of the on-farm production procedure and on grazing modalities closely following ecological processes in order to ensure the renewal of resources in the long term (Jouven et al, 2010; Dumont et al, 2013). Worldwide, in pastoral farming systems of dairy sheep and other ruminant species, feed requirements are 
covered to a varying degree through grazing of local fodder resources under a range of management systems (FAO, 2001). Grazing on a diversity of fodder plant species on rangelands also aids the conservation of landscapes (D'Ottavio et al, 2016) and limits soil erosion resulting from continuous cropping (Schnabel et al, 2009) in a way that is not competing with the use of land for other food production. Moreover, grazing of local resources promotes the biological interactions between animals and their biophysical environment, providing an interesting basis to design agroecological production systems (Dumont et al, 2013).

Despite these benefits, pastoral farming systems are disappearing, mostly in disadvantaged areas, but also in favourable sites of North Mediterranean countries, leading to degradation of traditional rural landscapes (Hadjigeorgiou et al, 2005; Caballero et al, 2009). The disappearance of pastoral activity in many regions in recent decades has revealed the importance of sustainable livestock management for environmental conservation. The absence of pastoralism has had negative consequences on biodiversity and ecosystem services, particularly in marginal areas traditionally used for this activity (Constanza et al, 1997). In many ecosystems with a deep-rooted grazing tradition, such as those of the Mediterranean (Hadjigeorgiou, 2011), the withdrawal of livestock farming activities has led to broad negative changes in the richness and diversity of plant species (Sternberg et al, 2000). Moreover, the abandonment of pastoral farming has led to modification of various interspecies interactions, affecting negatively, for instance, pollinators, herbivorous insects, parasitoids and birds (Plieninger et al, 2006; Dover et al, 2011). Similarly, this change favoured woody vegetation encroachment, leading to the accumulation of fuel biomass and consequently raising the danger of wildfires (Rosa-García et al, 2012). At the same time, ruminants' farming systems have evolved towards intensive ones and established in more accessible areas, such as lowlands and hilly areas of the mainland. Examples include reports on zero grazing in Castilla-Leon in Spain or sedentary intensive or semi-intensive systems in Greece (Caja and de Rancourt, 2002; de Rancourt et al, 2009), the abandonment of winter transhumance under agricultural pressure in the Ebro valley in Spain (Caballero et al, 2009) or the replacement of permanent grasslands by agriculturally improved pastures in Italy (Porqueddu et al, 2017).

In parallel, the evolution of flock composition in breeds and their crosses shows different patterns in Mediterranean regions subjected to intensification of farming systems and decreased use of native grazing resources. For example, in north and central Spain, as well as in Greece, farms with highly productive sheep breeds and their crosses coexist with those of local sheep breeds $^{1}$ (e.g. (de-la Fuente et al, 2006; Perucho et al, 2018). However, in other North Mediterranean regions, also subjected to intensification of farming systems, local breeds remain the main genetic resources in sheep farming. In the South of France, for instance, the BlackFace Manech and the Red-Face Manech are traditionally raised due to their hardiness in the transhumant systems of the West Pyrenees, although the Red-Face Manech now prevails over the Black-Face Manech in most intensive farming systems of the area (Labatut, 2009; Lauvie et al, 2015). Likewise, in the Crau region in France the Merino breed is used due to its specific transhumance ability, but it is also raised in many different sedentary farming systems, including mixed farming systems with an intensive use of land, based on cereals and hay cropping (Moulin et al, 2004; Lauvie et al, 2015). Moreover, holdings with local sheep breeds are found in many different biogeographical regions in Italy under sedentary or itinerant systems often combined with cropping (Caballero et al, 2009).

We thus hypothesized that the use of local breeds may not systematically ensure the preservation of pastoral practices in Mediterranean dairy sheep farming systems. In order to test this hypothesis, we explored holdings using different livestock breeds, as well as the evolution of their feeding systems with emphasis on pastoral practices. In particular, we focused on two production territories where dairy sheep farming systems were based on the use of different livestock breeds or their crosses, while they were subjected to similar trends towards intensification. Each case study brought up features from different situations to illustrate our argumentation.

\section{Material and methods}

\section{Choice of the study areas and specific objectives}

Holdings with different livestock breeds considered in the study were those with a) local sheep breeds traditionally raised in pastoral systems, b) highly productive breeds (either exotic or native, raised in more intensive farming systems) and c) crosses of these breeds. The evolution of pastoral practices was analysed through two approaches, (i) a direct one: mid-term analysis of changes in feeding systems (changes in grazing lands and supplementation), and (ii) an indirect one: a study of the diversity of feeding systems found in a territory at any one time and their past trajectories of intensification. The choice of the approach depended on the genetic resources considered. The two study areas chosen to cover this diversity of situations towards livestock breeds and feeding systems were the regions of Thessaly (central Greece) and Corsica (South of France).

\footnotetext{
${ }^{1}$ Local breeds are defined in this paper as breeds linked to a specific territory (e.g. Georgoudis et al, 2001; Loukovitis et al, 2016; Perucho, 2018)
} 
The outputs of these two case studies hereinafter are successively presented in the results section.

Thessaly is a region of central Greece composed of two central plains occupying half of the land area and bordered by mountainous chains that are traditional transhumance regions (Sivignon, 1975). The lowland part of Thessaly is characterized by a continental climate with cold winters, hot summers, and wide annual temperature ranges, while in the mountainous part summer temperatures are cooler. Typical grazing areas both in lowlands and highlands are composed of both grasslands and shrublands. In the last few decades, the region's holdings were subjected to an intensification trend centred on harvested feeds, encouraged by a combination of various subsidies, a favourable economic context (low price for feeds compared to the price of milk) or by the proximity of crops for animal consumption in the lowlands (Perucho et al, 2015). In this context, highly productive breeds with high feed requirements were progressively adopted since the 1970s. Nowadays, the breeds used by sheep farmers are multiple and include the three above mentioned categories, ranging from local breeds under recording schemes (e.g., the Karagouniko breed) or conservation programmes (e.g., the Kalarritiko breed) and other local animal populations, to highly productive breeds raised in purebred or crossbred flocks. Several changes in the genetic composition of the flocks were taking place at the time of the study. The objective of data collection in this region was (i) to understand the farmers' reasoning for choosing the specific breeds composing current flocks, and to identify among them the reasons linked to the feeding system in place (data set T1), and (ii) to compare recent changes of flock genetic composition and changes of feeding systems and identify possible causal relations (data set T2).

Corsica is an island in the South of France structured around two central mountainous ranges bordered by a narrow plain on the eastern side of the island. Below an altitude of $1200 \mathrm{~m}$ (all sampled farms were located below this altitude), the typical rangeland vegetation is composed of shrublands and woodlands and the climate is Mediterranean with a marked summer drought period and irregular rainfalls with local variations due to microclimates and altitudinal gradients (Gamisans, 1999). Sheep farming in Corsica is considered as pastoral, but has evolved since the 1960s towards an increasing use of cultivated grasslands and supplementation levels, and a decrease of transhumance (Santucci, 2010; Choisis and Vallerand, 1992). Nowadays, in spite of this intensification process, the Corsican sheep breed, traditionally raised in pastoral farming systems, is almost exclusively used in the region. Dairy sheep farming thus relies on purebred Corsican breed flocks, of which approximately $15 \%$ were included in the ewe breeding scheme of the Corsican breed in 2015. The objective of the data collection in this region was to investigate the different feeding systems in which this local breed is currently raised and identify possible differences in the pastoral components of these feeding systems. Additional information on breeding practices (culling and replacement rates) was collected at the same time in order to identify whether the feeding system could impact, if not on the reared breed, at least on its management through culling and replacement.

\section{Data collection}

The three data sets that were considered in the study to respond to the above mentioned specific objectives are presented in Table 1. Data were collected between October 2014 and May 2016 (dataset T1) and in 20162017 (dataset T2 and C1) through semi-structured interviews with farmers.

The sampling method for both case studies covered a diversity of feeding systems and focused on different sheep breeds. Information on regional feeding systems and their geographical distribution was obtained from the existing literature for Corsica (Paoli et al (2014) and Thessaly (Goussios et al, 2014; Perucho et al, 2015). In samples of $\mathrm{C} 1$ and $\mathrm{T} 1$ datasets, for purebred flocks of local breeds, attention was paid to address both flocks participating in the breeding scheme and flocks not participating in the breeding scheme. For dataset $\mathrm{T} 2$, interviews were focused on the changes from local breeds to their crosses with highly productive breeds and thus concerned flocks whose composition has evolved from local breed populations towards crossbred animals.

The interviews performed included close-ended and open-ended questions. Farmers' responses could have different levels of detail depending on the respondent, but in all cases, interviews gave specific attention to the collection of comprehensive information on on-farm practices (Kaufmann, 2011). The interviews were held face-to-face, while clarifications and additional information were subsequently obtained through telephone interviews, when needed.

Data collected and considered in the study are presented in Table 1. In interviews $\mathrm{C} 1$, the management of replacement and culling rates was considered under routine situations and perturbations, including the interannual variations of fodder on offer. In interviews T1, the selection of breeds composing the flocks and the crossbreeding strategy were explained by the farmers through their reasoning for choosing or rejecting each breed with respect to its characteristics. Interviews T2 were conducted on the basis of the conceptual framework of the analysis of the changes in livestock farming systems (Moulin et al, 2008), and they aimed to identify non-varying objects and sequences of transformations or progressive modifications to the components of the farming activity. For this purpose, farmers informed the interviewer about the year they began to change the initial genetic composition of their flock, mostly through performing crossbreeding with highly productive breeds. Data were collected for the year preceding the first introduction of a new breed in the flock and for the years during which a change occurred in these components, along with the 
Table 1. Characteristics of data collected in this study

\begin{tabular}{|c|c|c|c|}
\hline Study area & \multicolumn{2}{|c|}{ Thessaly } & Corsica \\
\hline ID data set & $\mathrm{T} 1$ & $\mathrm{~T} 2$ & $\mathrm{C} 1$ \\
\hline Data collection mode & \multicolumn{3}{|c|}{ Semi-structured interviews with farmers } \\
\hline Number of farms & $\mathrm{N}=42$ & $\mathrm{~N}=14$ & $\mathrm{~N}=30$ \\
\hline Targeted sample & $\begin{array}{l}\text { Diversity of flock genetic } \\
\text { compositions - Diversity of } \\
\text { feeding systems }\end{array}$ & $\begin{array}{l}\text { Crossbred flocks with highly } \\
\text { productive breeds } \\
\text { (previously local breeds) - } \\
\text { Diversity of feeding systems }\end{array}$ & $\begin{array}{l}\text { Purebred flocks of Corsican } \\
\text { breed ewe - Diversity of } \\
\text { feeding systems }\end{array}$ \\
\hline $\begin{array}{l}\text { Data collected and } \\
\text { considered in the study }\end{array}$ & $\begin{array}{l}\text { Agricultural land } \\
\text { composition, Grazing and } \\
\text { feeding management, Flock } \\
\text { composition, Breeds and } \\
\text { crossbreeding strategy }\end{array}$ & $\begin{array}{l}\text { Changes in: Supplementation } \\
\text { diet, Grazing management, } \\
\text { Surface and use of land, } \\
\text { Breeds involved in the flock } \\
\text { genetic composition }\end{array}$ & $\begin{array}{l}\text { Agricultural land } \\
\text { composition, Grazing and } \\
\text { feeding management, Flock } \\
\text { composition, Replacement } \\
\text { and culling }\end{array}$ \\
\hline
\end{tabular}

reasons motivating the change. All relevant changes were recorded until the year of the study.

\section{Definition of the pastoral components}

A range of definitions of pastoral systems can be found in the literature (Tchakerian, 2008; FAO, 2001). These definitions are mainly based on the presence or absence of the following components: a) seasonal movements of grazing animals, b) nature of grazing areas, c) proportion of the diet relying on native vegetation and d) knowledge and know-how related to grazing practices. In this paper, the term pastoral components" is used to describe the modalities of use of spontaneous vegetation (characteristics of grazing areas) and its relative importance in the feeding systems. More information on the variables considered is provided in the following section.

\section{Data analysis}

\section{Thessaly}

Data collected in Thessaly were analysed in two steps.

In the first step, using data set $\mathrm{T} 2$, the chronology of changes in feeding systems (supplementation levels and composition, importance of grazing and natural pastures, area for cropping animal feeds) and flock genetic composition (breeds introduced in the flock or abandoned), were described. The pastoral components of the feeding systems were defined according to the following modalities: low supplementation levels and high level of use of natural pastures. We analysed the evolution of these pastoral components by comparing the variations of supplementation levels, as well as the variations, in the use of natural pastures and crops for animal feeds over time. We either compared two values at different time points or used qualitative data on the evolution of the variables over time, (represented by triangles in Figure 1). Then, possible causal relations between changes in the feeding system and change in flock genetic composition were identified and addressed as follows: (i) defining the level of adaptation of the new genetic composition of the flock to the existing feeding system, as observed by the farmer, then (ii) detailing the different responses of the farmers to offset any failure in adaptation (see results).

Then, among the range of farmers' responses (T2), we focused on the reintroduction of breeding animals from local rustic breeds (Karagouniko breed), in order to reinstate the flock's adaptation to the existing feeding system. Among the reasons for choosing local rustic breeds, specific characteristics related to the hardiness of the breed and associated constraints of the feeding system were listed. This reasoning was compared to outputs of interviews T1 on the reasons for introducing or rejecting different breeds in the flock (see also Table 4). The effect of such reintroduction was discussed by considering the evolution of the feeding system after the reintroduction of a local breed (T2).

\section{Corsica}

In Corsica, farming systems were characterised in terms of the feeding system and the breeding practices (replacement and culling). The related descriptors are presented in Table 2. Among the five descriptors of the feeding system presented in Table 2, the variables used to describe pastoral components were, a) the percentage of flock's energy requirements covered through grazing at the annual level, b) the part of cultivated grasslands in the total agricultural area of the holding and c) the nature of the grazing areas. The percentage of the flock's annual energy requirements covered through grazing was derived from the total energy requirements minus the percentage covered by supplementary feed (roughage and concentrates) using feed tables (INRA, 2007). Descriptors of breeding practices (replacement rate in routine situations and under variations of fodder offer, see Table 2) expressed the strategies implemented by the farmers to secure the necessary fodder for their flocks, under inter-annual climate fluctuations.

In order to compare farms according to these two categories of variables, the different modalities were represented for each farm, on coloured and greyscale matrix (Bertin, 1983). This representation allowed the differentiation of farms, with flocks of Corsican sheep breed, into a range of feeding systems and the identification of specific breeding practices (aimed to 
Table 2. Variables built for the analysis of the data derived from the C1 interviews, subsequently used for Bertin's graphical representations

\begin{tabular}{lll}
\hline Category of variable & \multicolumn{1}{c}{ Variable } & \multicolumn{1}{c}{ Variable code } \\
\hline & Role of grazing in covering total flock energy requirements & ROLE GRAZING \\
& Self-sufficiency in hay production & HAY PRODUCTION \\
Feeding system & Share of cultivated grasslands to the total agricultural land & CULTIVATED GRASSLANDS \\
& Location of the farm & LOCATION \\
& Practice of transhumance & TRANSHUMANCE \\
Replacement and & Routine replacement rate & REP RATE \\
culling (results in & Influence of variation of forage availability on culling rate & FORAGE VAR/CULL RATE \\
Figure 3) & Influence of variation of forage availability on replacement rate & FORAGE VAR/REP RATE \\
\hline
\end{tabular}

secure fodder on offer) in groups of farms raising the same breed under different feeding systems.

\section{Results}

\section{Comparative evolution of feeding systems and crossbreeding practices in Thessaly}

Figure 1 illustrates changes in the feeding systems (in terms of supplementation, grazing and crops for animal consumption) and the breeds introduced in the flocks of 14 dairy sheep farms in Thessaly after the first crossbreeding with a highly productive breed (first yellow square of each line). Among these numerous changes of breeds and feeding systems, several were justified by farmers after a failure of the new breed to adapt to the existent feeding system. Starting from these specific cases, we analysed the different drivers of evolution of breeds and feeding systems in the short and long-term.

\section{Introducing highly productive breeds displayed a lack of adaptation to existing feeding systems}

A lack of adaptation of newly introduced, highly productive breeds (or their crosses) in the flock to existing feeding strategy and grazing conditions was mentioned by nine farmers. These inconsistencies between breeds and feeding systems took three forms: (i) the breed/crossbreed was deemed not hardy enough to function under existing grazing conditions; (ii) the feeding strategy implemented for the breed was considered economically unsustainable; and (iii) the various breeds, raised simultaneously in the flock, had different feeding requirements, but it was not practical to implement a different feeding practice for each of them (Table 3).

Three types of farmers' responses (adjustments) to this lack of adaptation were identified. The first type was the modification of the feeding/grazing strategy towards decreasing the role of native resources in the applied production system, represented by red stars in $\$$. The second type consisted of the rejection of the highly productive breed in use and/or the testing of a new breed: farmers adopted an exploratory behaviour towards locally available breeds, leading to several changes in breeding animals in a short time period, according to availabilities offered by the market and consultation with other farmers in the region and elsewhere. The third type of farmers' response was the reintroduction of breeding animals from the local hardy Karagouniko breed in the herd, represented by brown triangles in Figure 1.

In some farms, the failure of the highly productive breeds to adapt to the feeding system in place was not explicitly mentioned by the farmer, but feeding systems were modified after their introduction. Some of these changes in feeding systems occurred in the general frame of the intensification of farm production means, i.e. the purchase of highly productive breeding animals (yellow squares in Figure 1) came with an investment in feed quantity and quality, housing, equipment and task mechanization in order to maximize the expression of the specific breed's productive potential. The introduction of a highly productive breed and the decrease of grazing and/or the change in diet quantity or quality generally occurred simultaneously or within a short time period after breed introduction (example of changes in farms $1,2,3,4,5$ or 6 during the decade 2000-2010, Figure 1).

Other changes in feeding systems were driven by the following four factors: (i) a change in land access (example of farm 8 since 2003, Figure 1, (ii) economic or climatic perturbations, (iii) a modification of the role of sheep farming in the family's income and (iv) the increase in average flock size. They occurred at different moments regardless of the change of breed (examples of changes in farms 9 and 13 in 1995 and 1997-1998, respectively). The above mentioned drivers of change could be combined (one perturbation implies farm intensification). For example, in mixed farming holdings, traditionally based on cash crops and sheep farming (farms 3,5 and 6 in Figure 1), the combination of decreasing cotton prices (since the 2000's) and the decoupled subsidies for cotton crops (since 2006) led to an increasing role of sheep farming in the family income, together with the search for new alternatives to cotton crops. According to farmers' economic possibilities, subsequent changes in sheep farming activities were immediate (farms 5 and 6) or progressive (farm 3) and included the testing of different, highly productive breeds combined with high supplementation levels and 


\section{\begin{tabular}{|c|c|c|c|c|c|c|c|}
\hline $1980-1985$ & $1985-1990$ & $1990-1995$ & $1995-2000$ & $2000-2005$ & $2005-2010$ & $2010-2015$ & $2015-2020$ \\
\hline
\end{tabular}}

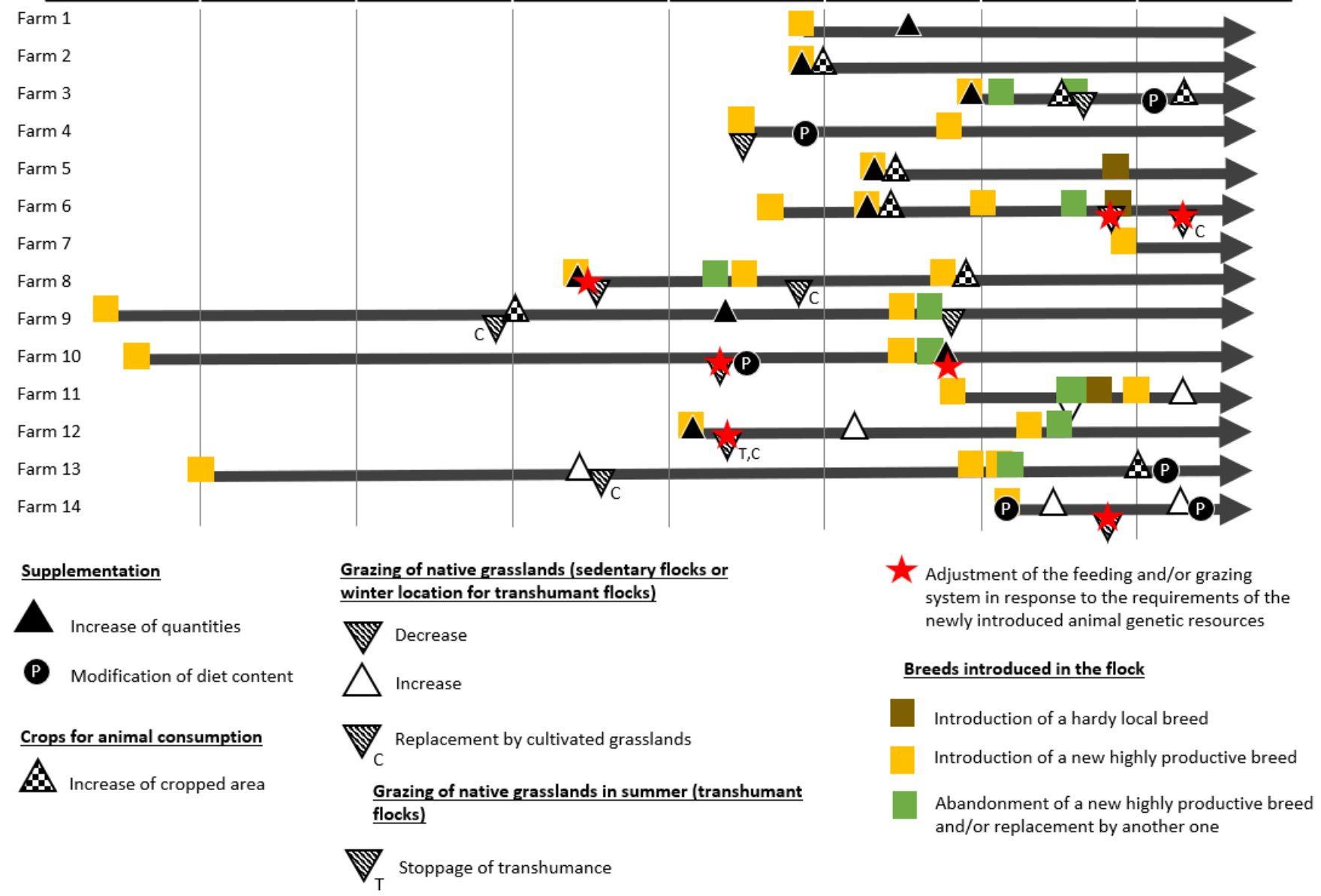

Figure 1. Comparative evolution of the flocks' breed compositions as well as the feeding and grazing systems in 14 dairy sheep farms in Thessaly, Greece.

the replacement of cotton crops by crops destined for animal feeding.

\section{Introduction of Karagouniko local breed for hardiness was not necessarily associated with maintenance of pastoral components}

The reintroduction of the local Karagouniko breed was operated by farmers in three of the nine farms for which inconsistencies between flock genetic composition and feeding system were mentioned. In farmers' statements, the characteristics of the highly productive breeds/crossbreeds forcing such changes in the flock genetic composition were the following: high sensitivity to thermic stress $(n=2)$, high cost of feeding $(n=1)$, high cost of animal health care or high sensitivity to mastitis $(n=2)$, inefficient performance on pasture $(n=1)$, a lack of adaptation to transhumance $(n=1)$, and difficulty in hand milking $(n=1)$. Likewise, the results from the $\mathrm{T} 1$ interviews indicated that the dairy sheep farmers of Thessaly utilised local breeds in their holding in order to improve the hardiness of the flock (in terms of adaptation to pastoral conditions) and rejected highly productive breeds for their incapacity to do so. These abilities and the breeds used or rejected for their corresponding characteristics are presented in Table 4.
However, in the medium and long-term, the pastoral components of the feeding systems of those three farms were not necessarily maintained. In the first farm (farm 5), maintaining grazing on communal grasslands, in order to keep feeding costs low, was part of the farmer's strategy according to his statement. Reintroduction of Karagouniko purebred animals aiming to keep a hardy flock, several years after the first crossbreeding, allowed the farmer to maintain this grazing practice for the following years (farm 5 in Figure 1). In a second farm (farm 6 in Figure 1), reintroducing the Karagouniko breed, through crossing, was motivated by the low capacity of the highly productive breeds to cope with climatic constraints. However, the newly composed crossbred flock remained disappointingly sensitive to thermal stress, as well as to health risks on communal grasslands, which led the farmer to decrease grazing a few years after the introduction of the local breed. In a third farm (farm 11 in Figure 1) using native grasslands (including summer pastures through transhumance) was part of the farmer's strategy but, ultimately, the maintenance of this practice competed with workload management. In this case, crossbreeding with the local breed temporarily delayed the stoppage of transhumance. However, the introduction of machine 
Table 3. Components of the feeding system and the traits of the breed involved in the different forms of inconsistencies mentioned by farmers in Thessaly

\begin{tabular}{|c|c|c|}
\hline Inconsistency (number of farms) & $\begin{array}{l}\text { Component of the feeding system at } \\
\text { stake }\end{array}$ & $\begin{array}{l}\text { Traits of the breed at stake (number of } \\
\text { mentions) }\end{array}$ \\
\hline \multirow{4}{*}{ Lack of hardiness $(n=8)$} & Grazing conditions (Climatic conditions) & Sensitivity to thermal stress $(n=1)$ \\
\hline & $\begin{array}{l}\text { Grazing conditions (Duration of } \\
\text { grazing/nature of the foraging resource) }\end{array}$ & $\begin{array}{l}\text { Feeding mode leading to sensitivity to } \\
\text { mastitis and ruminal pathologies }(n=1)\end{array}$ \\
\hline & Grazing conditions (Presence of pathogens) & $\begin{array}{l}\text { Sensitivity to vector-borne diseases } \\
(\mathrm{n}=2)\end{array}$ \\
\hline & $\begin{array}{l}\text { Grazing conditions (Distance and } \\
\text { topography) }\end{array}$ & Walking ability $(\mathrm{n}=3)$ \\
\hline \multirow{3}{*}{ Feeding costs $(n=5)$} & Grazing conditions (Open-field pastures) & Grazing behaviour $(n=2)$ \\
\hline & $\begin{array}{l}\text { Feed supply (quantities at the multiyear } \\
\text { scale) }\end{array}$ & Longevity $(\mathrm{n}=2)$ \\
\hline & Feed supply (quantities at the yearly scale) & Feeding requirements $(n=3)$ \\
\hline Competition between breeds $(n=1)$ & Feed supply (quantities at the yearly scale) & Feeding intake $(\mathrm{n}=1)$ \\
\hline
\end{tabular}

milking led this farmer towards a sedentary system (this is not presented in the figure, but it was planned as a short-term project by the farmer at the year of the interview). It is also interesting to mention that the modalities of the introduction of the local breed in these three farms were limited to the introduction of breeding males in the specific year that the problem was observed and it was not followed by a concrete crossbreeding plan with the introduced local breed.

\section{Local purebred flocks in a diversity of feeding systems in Corsica}

Currently, different feeding systems can be observed among local purebred flocks of Corsica (Corsican sheep breed), ranging from the most pastoral to the most intensive in feeding inputs and land use and including both transhumant and sedentary flocks.

Figure 2 presents a classification of five types of feeding systems (FS1 to FS5) according to the role of grazing in covering the energy requirements, the type of grazed pastures and the farmers' strategy with respect to the provision of hay. Most of the pastoral systems (characterized by less harvested feed energy used compared to that of grazed native resources) are found in southwestern and central Corsica (FS1 and FS2), the most intensive feeding systems (in terms of feeding inputs and workload for fodder production) are located in the eastern coastal lowlands (FS5), and the intermediate feeding systems are found in all locations of the island (FS3 and FS4). This current situation of local breed dairy sheep farming conditions in Corsica reflects a trend towards the securing of feeding systems, either by on-farm fodder production in areas with favourable agroecological conditions, or by hay purchased at the market. The diversity of land use in Corsica, for the 206 dairy sheep farms using the Corsican breed, has also been documented by Perucho et al (2020)

Table 4. Breeds' traits motivating the introduction or rejection of a specific breed in the flock: the case of traits linked to pastoral farming. Hardiness (or a similar term) was used by farmers to characterize the overall ability of the breed to withstand the constraints of its raising conditions.

\begin{tabular}{lll}
\hline $\begin{array}{l}\text { Reasons for introducing or rejecting a } \\
\text { specific breed (traits linked to pastoral } \\
\text { farming) }\end{array}$ & $\begin{array}{l}\text { Percentage of sampled farmers } \\
\text { mentioning the trait }(\mathbf{n}=42 \\
\text { farmers) }\end{array}$ & $\begin{array}{l}\text { Breeds used (in bold) or rejected } \\
\text { (normal font) }\end{array}$ \\
\hline $\begin{array}{l}\text { Ability to handle transhumance } \\
\text { Low sensitivity to cold and high humidity }\end{array}$ & $\begin{array}{l}14 \%(\mathrm{n}=6) \\
50 \%(\mathrm{n}=21)\end{array}$ & $\begin{array}{l}\text { Kalarritiko breed } \\
\text { Karagouniko breed and local } \\
\text { populations Chios, Lacaune, and }\end{array}$ \\
Low sensitivity to heat & $45 \%(\mathrm{n}=19)$ & $\begin{array}{l}\text { Frizarta/Friesian breeds } \\
\text { Karagouniko and Awassi breeds }\end{array}$ \\
Hardiness & $48 \%(\mathrm{n}=20)$ & $\begin{array}{l}\text { Frizarta/Friesian and Assaf breeds } \\
\text { Karagouniko, Kalarritiko, Piliou and } \\
\text { local populations } \\
\text { Chios and Lacaune breeds } \\
\text { Karagouniko breed }\end{array}$ \\
\hline
\end{tabular}



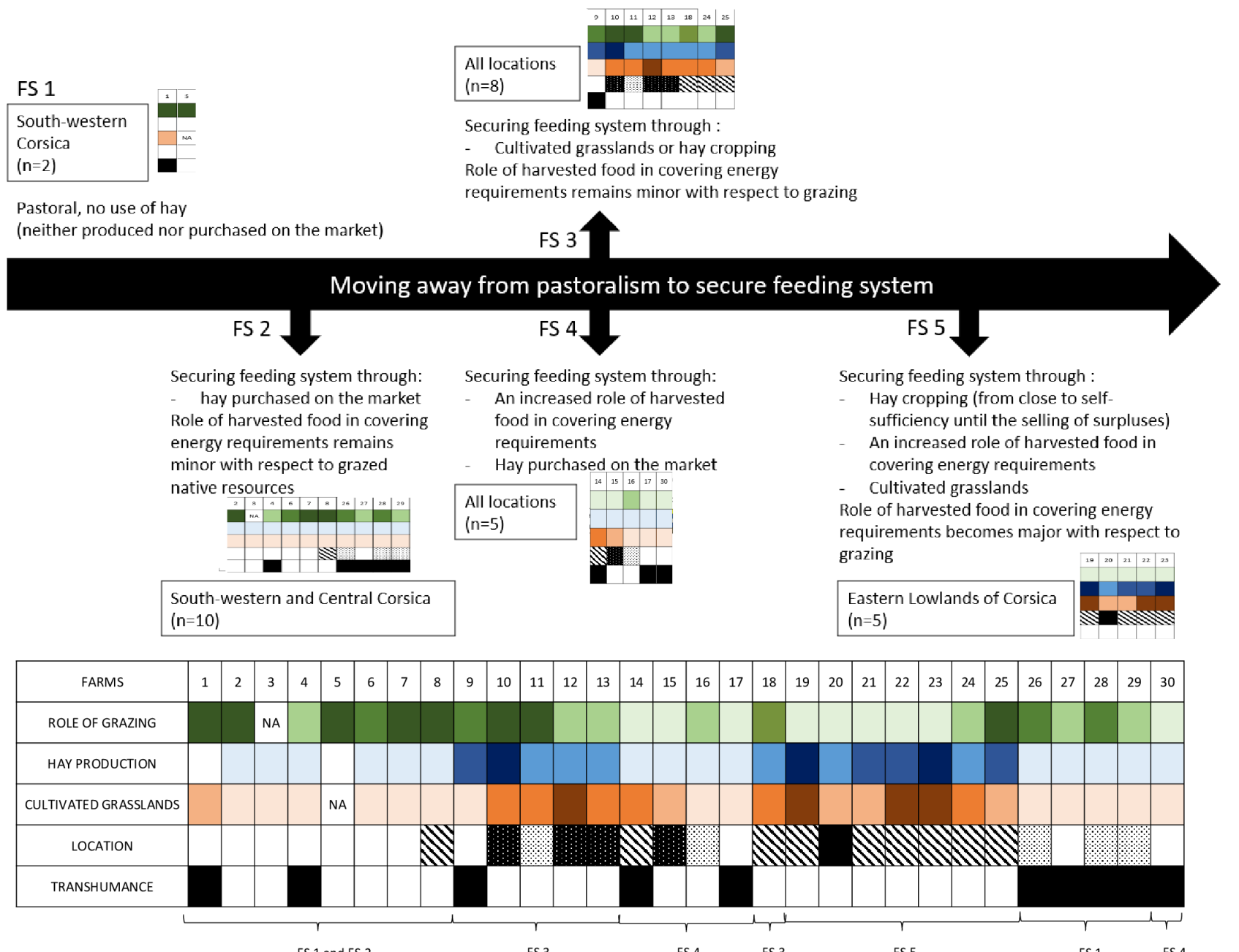

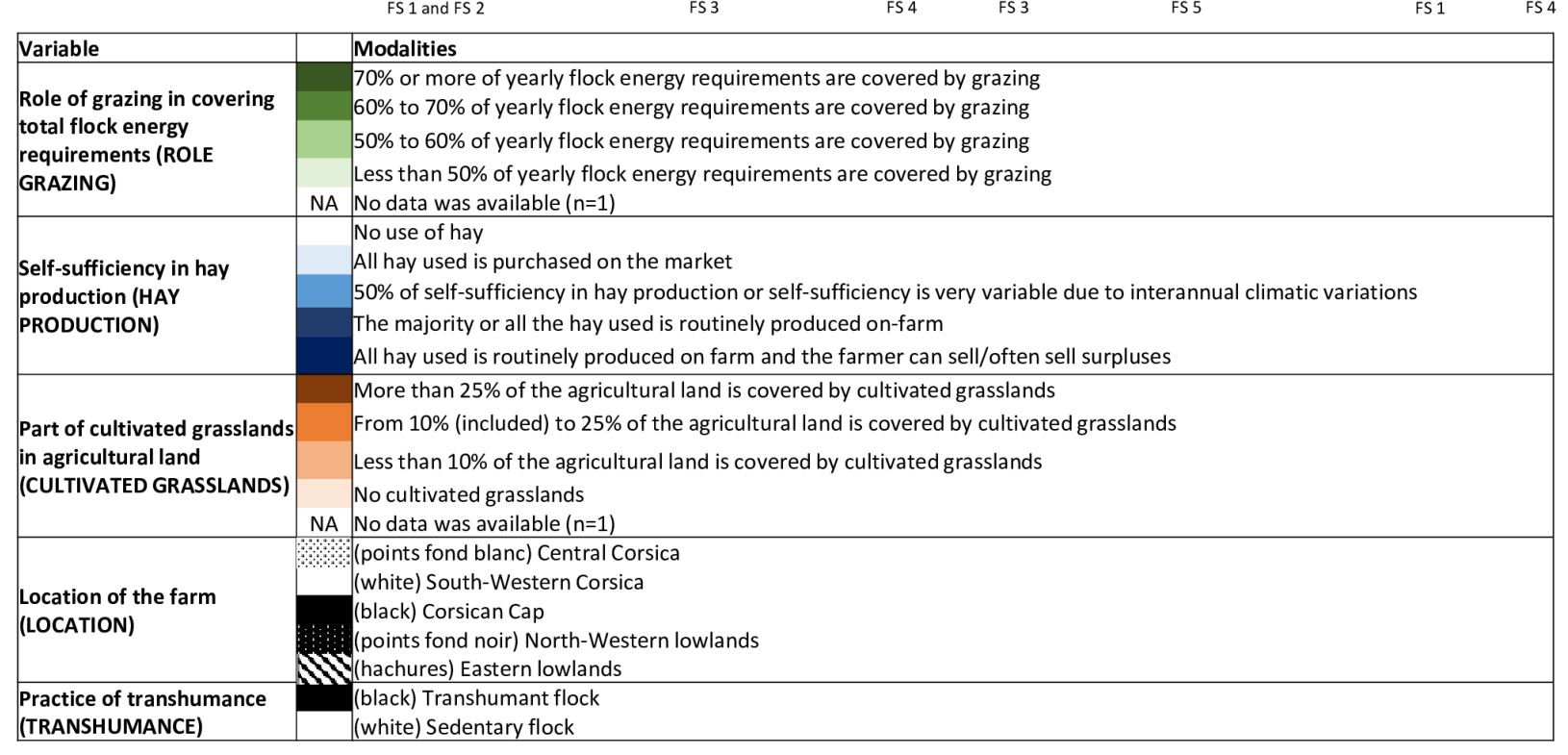

Figure 2. Diversity of the feeding systems among the local purebred flocks in Corsica (results on 30 farms) 


\section{Adaptation to variations of fodder on offer through replacement and culling management in local purebred flocks of Corsica}

In addition to the use of local breeds in purebred flocks, several of the interviewed farmers performed specific breeding practices in order to maintain the same feeding system in spite of the variations in climatic conditions and subsequent fodder offer. These breeding practices consisted of adjusting the demography of the flock according to inter-annual variations of fodder on offer. In some pastoral systems of southern and central Corsica (farms 1, 2, 3 and 4; included in FS1 and FS2, Figure 3, this consisted of increasing the replacement rate in years with good forage offers (FORAGE VAR/REP RATE, line 4 of the table in Figure 3) and of reversing the practice in years of low forage offers. Moreover, in pastoral systems FS1 and FS2, the observed replacement rates were generally low (less than 20\%, REP RATE, see line 2 of the table in Figure 3). Another adaptation of the flock demography consisted of increasing the culling rate in order to limit the number of animals that feed during the lambing period of the following year (farms 11, 12, and 13, FORAGE VAR/CULL RATE, line 3 of the table in Figure 3). This practice was observed in farming systems relying partly on cultivated forage (FS3) in areas of the island impacted by a dry microclimate (e.g. north western lowlands), resulting in variable fodder production from one year to another. These examples, although concerning only a small number of farmers of the sample, demonstrate that the use of a local breed might be combined with other breeding practices so that the farmer is able to maintain the same feeding system from one year to another.

\section{Discussion}

Our results indicate that the practice of crossbreeding with highly productive breeds in Thessaly is often connected with the intensification of feeding by increasing the quantity of feed inputs and modifying the diet with the aim of improving its quality. Similarly, the use of local breeds is usually linked with the applied pastoral practices and prevailing climatic conditions. Boyazoglu and Hatziminaoglou (2005) described the long-term evolution of feeding systems in the European part of the Mediterranean basin, characterised by a decrease in transhumance and the use of grazing areas, while the population of small ruminants maintained its genetic composition. On the other hand, Couix et al (2016) showed that, in dairy cow holdings, the replacement of the Holstein breed by dual purpose local breeds in the western part of France was associated with an overall evolution of the farming systems towards decreased production costs, including the costs associated with the feeding system. In this study, a change in breed was often followed by the adoption of pasture-based feeding systems. Samdup et al (2010) analysed the adoption of crossbreeding with different exotic, highly productive breeds in a range of cattle farming systems in Bhutan (from extensive to intensive livestock farming systems) and the impact of crossbreeding on such farming systems four years after its implementation. They observed a lower adoption rate of crossbreeding in extensive and semi-intensive farms with the farms either keeping the local breed or rejecting one specific exotic breed (among the two introduced) due to its high feed requirements. The authors also mentioned that during lactation, crossbred cows were stall fed, resulting in reduced grazing in forest and natural grasslands in comparison to local cattle (Samdup et al, 2010). The same conclusions were drawn in a study in Ethiopia (Roschinsky et al, 2015), where most of the cattle farmers adopting crossbreeding with exotic breeds changed their grazing and feeding management towards restricted grazing and the purchase of compound feeds or household by-products, while feed shortages and feed prices were the drivers for rejecting the practice of crossbreeding. Caballero et al (2009) also mention the decline of some indigenous breeds in Spain, Italy and Greece and the abandonment of extensive livestock farming in marginal areas. Apart from diachronic studies, studies dealing with farmers' preferences for breeds' traits emphasize the key role of local breeds' adaptive traits in pastoral systems (Kosgey et al, 2008; Tamou et al, 2018) and the preference for exotic breeds in agropastoral systems benefitting from best pastures and climatic conditions (Konig et al, 2015). These results agree with the first part of our results associating, on the one hand, crossbreeding for higher productivity with feeding intensification and, on the other hand, local breeds with lower feeding inputs in pastoral systems.

However, these two associations are not systematically observed, and farmers do not necessarily abandon raising local breeds following an intensification process. The example of Corsica, where one local breed is raised under feeding systems with different levels of intensification, and the one of Thessaly, where a variety of genetic types can be found at different stages of the intensification process, suggest that additional studies are needed in order to more convincingly conclude whether coevolution of local breeds and feeding systems is regionally univocal. The data collected through interviews should be compared with the physiological and behavioural responses of highly productive sheep breeds and their crosses in pastoral farming systems in North Mediterranean countries. Methods to predict breeds' suitability to environmental conditions are proposed, in this sense, by (Lozano-Jaramillo et al, 2018) and (Marshall, 2014), but these concern South Mediterranean or tropical systems. In the case of North Mediterranean countries, there are fewer pastoral components and the climatic conditions are milder, but the need for adaptive potential of the animals to similar environments is increasing in importance due to intensifying climatic changes (Hoffman, 2013). In this sense, learning processes regarding grazing (Meuret and Provenza, 2014) and genetic selection should also be considered 


\begin{tabular}{|c|c|c|c|c|c|c|c|c|c|c|c|c|c|c|c|c|c|c|c|c|c|c|c|c|c|c|c|c|c|c|}
\hline FARMS & 1 & 2 & 3 & 4 & 5 & 6 & 7 & 8 & 9 & 10 & 11 & 12 & 13 & 14 & 15 & 16 & 17 & 18 & 19 & 20 & 21 & 22 & 23 & 24 & 25 & 26 & 27 & 28 & 29 & 30 \\
\hline REP RATE & & & & & & & & & & & & & & & & & & & & & & & & & & & & & & \\
\hline FORAGE VAR/CULL RATE & & & & & NA & & & & NA & & & & & & & & & & & & & & & & & & & & & \\
\hline FORAGE VAR/REP RATE & & & & & NA & & & & NA & & & & & & & & & & & & & & & & & & & & & \\
\hline
\end{tabular}

\begin{tabular}{|c|c|}
\hline Variable & Modalities \\
\hline \multirow{3}{*}{$\begin{array}{l}\text { Routine replacement rate (REP } \\
\text { RATE) }\end{array}$} & Routine replacement rate is $20 \%$ or more \\
\hline & Routine replacement rate goes from $15 \%$ (included) to $20 \%$ (excluded) or minimum replacement rate in routine is $15 \%$ \\
\hline & Routine replacement rate is less than $15 \%$ \\
\hline \multirow{4}{*}{$\begin{array}{l}\text { Influence of forage variation on } \\
\text { culling rate (FORAGE VAR/CULL } \\
\text { RATE) }\end{array}$} & Forage variations from one year to another does not influence culling rate \\
\hline & A low forage offer can slightly increase culling rate \\
\hline & A low forage offer frankly increases culling rate \\
\hline & NA No data was available $(n=2)$ \\
\hline \multirow{4}{*}{$\begin{array}{l}\text { Influence of forage variation on } \\
\text { replacement rate (FORAGE } \\
\text { VAR/REP RATE) }\end{array}$} & Forage variations from one year to another does not influence female replacement rate \\
\hline & A high forage offer can slightly increase female replacement rate \\
\hline & A high forage offer frankly increases female replacement rate \\
\hline & NA No data was available $(n=2)$ \\
\hline
\end{tabular}

Figure 3. Adjustment of the flock demography according to the inter-annual variations of the fodder offers in Corsica $(\mathrm{C} 1, \mathrm{n}=30)$

when assessing the suitability of North Mediterranean breed types. Finally, our results illustrate that defining the "pastoral dimension" of North Mediterranean systems implies considering a set of pastoral components assessed not in terms of absolute value, but also in relative value: pastoral components of one farm are described with regard to the other farming systems of the area. Accordingly, detailing constraints of feeding systems by pastoral components might be useful in the assessment of breed suitability.

The fact that feeding systems in an area can evolve independently from animal genetic resources used there, is not analysed per se in current research, but rather is suggested by the diversity of factors known to affect the maintenance of pastoral components and the management of animal genetic resources. The evolution of small ruminant feeding systems towards decreased pastoral components is well documented in different Mediterranean countries (de Rancourt et al, 2009). The drivers of this decrease, as depicted in recent literature, echo the findings of the present study: the farmers wish to alleviate the labour-consuming tasks associated with the feeding system, which leads to a decrease in grazing (Aubron et al, 2016). Other factors such as the farmers' mind-set and their social environment, the absence of markets for products based on grazing, as well as land fragmentation have been shown to influence the decision to graze or not to graze in European dairy cow holdings (Dasselaar et al, 2020). In Greece, the economic context (in terms of prices and subsidies) favoured the choice of purchasing feed outside of the farm (Stefanakis et al, 2007;
Volanis et al, 2007; Hadjigeorgiou, 2011), together with other factors such as the low quality of spontaneous forage material, the difficulty to access communal rangelands and an inadequate rangeland management system. Other examples from small ruminant farming in Greece also illustrate that the legislative framework can force the settlement of nomadic farmers through specific requirements for facilities to comply with milk and stock hygiene standards, animal welfare and manure management (Hadjigeorgiou, 2011). Finally, the trend towards agricultural intensification in easily accessible productive lands led to land use changes through abandonment of mountainous areas in southern Europe and shrub encroachment in many remote areas formerly used for grazing (MacDonald et al, 2000; Caballero et al, 2009). This phenomenon is highly dependent on EU agricultural and natural conservation policies (Tzanopoulos et al, 2011).

Likewise, the diversity of factors affecting the evolution of animal genetic resources in flocks has to be taken into account. According to (FAO, 2015), the reported main causes of genetic erosion in 23 countries in Europe and the Caucasus (in response to openended questions) mostly consisted of (i) breeds not profitable/competitive or that have poor performance ( $48 \%$ of the countries), (ii) intensification of production or decline of traditional production systems or smallsized farms (39\% of the countries) and/or (iii) the introduction/increased use of exotic breeds (35\% of the countries). Indeed, the introduction of exotic breeds through uncontrolled crossbreeding (failure or absence of crossbreeding programmes) greatly compromised 
the conservation of local breeds (Leroy et al, 2016b). More than $20 \%$ of the above mentioned countries also mention problems in breed management linked to weak or absent management policies, programmes or institutions (FAO, 2015). Indeed, except for their adaptive traits, local breeds in European countries are also kept (being the first motivation) for their links with tradition and their importance in society and, unequally among countries and breeds, for the economic incentives and conservation programmes that benefit them (Gandini et al, 2010). In this context, the successes or failures faced by national genetic management programmes and the associated involvement of researchers in such management (Leroy et al, 2016a) directly impact the evolution of local breeds' populations. In Greece, for example, the state-run genetic management of local breeds has suffered several interruptions in financing, impacting the implementation of data recording (Georgoudis and Ligda, 2000). Together with unfavourable dairy policies, the problems in the implementation of breed management programmes have been impacting on, for example, the breeding scheme of the Karagouniko breed in Thessaly (e.g. Perucho et al, 2019). On the other hand, the financial support, through EU-funded agri-environmental measures, aimed at farmers raising local breeds threatened by extinction, together with the support provided to farmers in mountainous or disadvantaged areas, has succeeded in maintaining local breed populations over time, as is, for example, the case for the pastoral sheep farming systems of the Kalarritiko purebred flocks (National Rural Network, 2019).

\section{Conclusion}

The example of long-term changes in dairy sheep farms in Thessaly, Greece, indicated that dairy sheep farmers sometimes use local breeds in crossbred flocks in order to improve flock hardiness after a first crossbreeding with highly productive breeds. In this strategy grazing practices can be maintained and feeding costs reduced together with other health costs. In some cases, the shift to new exotic breeds was also considered as an alternative to local breeds in order to improve flock hardiness. However, any additional factors impacted the management of feeding systems, such as local trends towards intensification, access to production means (e.g. land, workforce, capital) and workforce management. This resulted in an evolution of feeding systems (decrease of grazing on native grasslands - increase of supplementation) not necessarily in accordance with the initial reason for the introduction of the local breed in the flock (the maintenance of pastoral components of the feeding system). Likewise, although the Corsican sheep breed is considered as hardy, its use could be maintained in different feeding systems including systems engaged in an intensification process. Finally, farmers in Corsica chose to act on flock structure to adapt to several constraints linked to the forage offer in their local purebred flocks. This result indicated that the use of a local breed in purebred or crossbred flocks should be combined with several other practices or conditions so that raising local breeds remains closely related to the pastoral activity.

By demonstrating a non-univocal co-evolution between local breeds and farming systems, this study highlights the need to better characterize local and exotic breeds' abilities as well as farmers' strategies to cope with different perturbations of their environment. This knowledge will help maintain pastoral systems in production territories and the livestock breeds associated with these territories.

\section{Acknowledgements}

This work was supported by the European Union through ERA-NET projects DoMEsTIC (ARIMNet, GA: KBBE 219262) and PERFORM (ARIMNet2, GA: 618127), by the Department of Nutritional Physiology and Feeding of the Agricultural University of Athens and the Corsican regional research funding scheme (CPER/CTC). The PhD thesis scholarship of the first author was funded by the Collectivité Territoriale de Corse.

\section{Author contributions}

The authors confirm contribution to the paper as follows: study conception and design: Lola Perucho, Anne Lauvie, Charles-Henri Moulin, Jean-Christophe Paoli, Christina Ligda; data collection: Lola Perucho; analysis and interpretation of results: Lola Perucho, Ioannis Hadjigeorgiou, Anne Lauvie, Charles-Henri Moulin, Jean-Christophe Paoli, Christina Ligda; draft manuscript preparation: Lola Perucho; manuscript revision: Lola Perucho, Ioannis Hadjigeorgiou, Anne Lauvie, Charles-Henri Moulin, Jean-Christophe Paoli, Christina Ligda.

\section{Conflict of interest statement}

The authors declare that no conflict of interest exists.

\section{References}

Aubron, C., Noël, L., and Lasseur, J. (2016). Labor as a driver of changes in herd feeding patterns: Evidence from a diachronic approach in Mediterranean France and lessons for agroecology. Ecological Economics 127, 68-79. doi: https://doi.org/10.1016/j.ecolecon.2016. 02.013

Bertin, J. (1983). Semiology of graphics: diagrams, networks, maps. (Madison: The University of Wisconsin Press).

Boyazoglu, B. J. and Hatziminaoglou, Y. (2005). Livestock genetic resources and production systems: a Mediterranean overview. Archivos Latinoamericanos de Producción Animal 10. url: https://www.alpa.uy/ PDF/Arch\%2010-1/100110.pdf.

Caballero, R., Fernandez-Gonzalez, F., Badia, R. P., Molle, G., Roggero, P., Bagella, S., D'ottavio, P., 
Papanastasis, V., Fotiadis, G., Sidiropoulou, A., and Ispikoudis, I. (2009). Grazing systems and biodiversity in Mediterranean areas: Spain, Italy and Greece. Pastos 39, 9-152.

Caja, G. and de Rancourt, M. (2002). Situation actuelle et perspectives de la production des ovins laitiers en Espagne. In L'Observatoire des Systèmes de Production Ovine et Caprine en Méditerranée : Chiffres clés et indicateurs de fonctionnement et d'évolution, ed. Dubeuf, J.-P., (Zaragoza: CIHEAM), volume 39 of Options Méditerranéennes: Série B. Etudes et Recherches, 57-66.

Choisis, J. P. and Vallerand, F. (1992). Ovins, caprins : Des filières en transformation. Economie Corse, IN-

SEE, 10-13.

Constanza, R., Arge, R., Groot, R. D., Farber, S., Grasso, M., Hannon, B., Limburg, K., Naeem, S., O’Neill, R. V., Paruelo, J., Raskin, R. G., Sutton, P., Den, V., and Belt, M. (1997). The value of the world's ecosystemic services and natural capital. Nature 387, 253-260. doi: https://doi.org/10.1038/387253a0

Couix, N., Gaillard, C., Lauvie, A., Mugnier, S., and Verrier, E. (2016). Des races localement adaptées et adoptées, une condition de la durabilité des activités d'élevage. Cah. Agric 25(650009). (in French). doi: https://doi.org/10.1051/cagri/2016052

Dasselaar, A. V. D. P.-V., Hennessy, D., and Isselstein, J. (2020). Grazing of Dairy Cows in Europe - An InDepth Analysis Based on the Perception of Grassland Experts. . Sustainability 12(1098). doi: https://doi. org/10.3390/su12031098

de la Fuente, L. F., Gabina, D., Carolino, N., and Ugarte, E. (2006). The Awassi and Assaf breeds in Spain and Portugal. In Proceedings of the 57th EAAP Annual Meeting of European Association of Animal Production (EAAP), 17-20.

de Rancourt, M., Fois, N., Lavin, M. P., Tchakerian, E., and Vallerand, F. (2009). Mediterranean sheep and goats production: An uncertain future. Small Ruminant Res 62, 167-179. doi: https://doi.org/10. 1016/j.smallrumres.2005.08.012

D'Ottavio, P., Francioni, M., Trozzo, L., Sedic, E., Budimir, K., Avanzolini, P., Trombetta, M. F., Porqueddu, C., Santilocchi, R., and Tode, M. (2016). Methods and approaches used for assessing ecosystem services provided by grazing systems. In Ecosystem Services and Socio-Economic Benefits of Mediterranean Grassland, Options Méditerranéennes. Série A : Séminaires Méditerranéens, CIHEAM.

Dover, J. W., Spencer, S., Collins, S., Hadjigeorgiou, I., and Rescia, A. (2011). Grassland butterflies and low intensity farming in Europe. Journal of Insect Conservation 15, 129-137. doi: https://doi.org/10. 1007/s10841-010-9332-0

Dumont, B., Fortun-Lamothe, L., Jouven, M., Thomas, M., and Tichit, M. (2013). Prospects from agroecology and industrial ecology for animal production in the 21st century. Animal 7, 1028-1043. doi: https://doi. org/10.1017/s1751731112002418
FAO (2001). Pastoralism in the new millennium. url: http://www.fao.org/3/y2647e/y2647e02.htm.

FAO (2015). The second report on the state of the world's animal genetic resources for food and agriculture, ed. B.D., S. and D., P. FAO Commission on Genetic Resources for Food and Agriculture Assessments, (Rome, Italy: FAO), 562p. url: http:// www.fao.org/3/a-i4787e.pdf.

Gamisans, J. (1999). La végétation de la Corse. (EdiSud).

Gandini, G., Avon, L., Bohte-Wilhelmus, D., Bay, E., Colinet, F. G., Choroszy, Z., Diaz, C., Duclos, D., Fernandez, J., Gengler, N., Hoving-Bolink, R., Kearney, F., Lilja, T., Maki-Tanila, A., Martin-Collado, D., Eijndhoven, M. M.-V., Musella, M., Pizzi, F., Soini, K., Toro, M., Turri, F., Viinalas, H., Consortium, E., and Hiemstra, S. J. (2010). Motives and values in farming local cattle breeds in Europe: a survey on 15 breeds. Animal Genetic Resources . doi: https://doi. org/10.1017/s2078633610000901

Georgoudis, A., Baltas, A., Tsafaras, C., Ligda, C., Danou, E., and Fragos, K. (2001). Developing biodiversity indicators for the livestock in Greece. In Proceedings from an OECD Expert meeting, 56-65.

Georgoudis, A. and Ligda, C. (2000). Small ruminant breeding programs in Greece.

Goussios, D., Tsiboukas, K., Anthopoulou, T., Anastasios, V., Gaki, D., Tozanli, S., Bencharif, A., and Lapujade, J. (2014). Developing the typical dairy products of Thessaly: diagnosis and local strategy.

Hadjigeorgiou, I. (2011). Past, present and future of pastoralism in Greece. Pastoralism 1(24). doi: https: //doi.org/10.1186/2041-7136-1-24

Hadjigeorgiou, I., Osoro, K., Almeida, J. P. F. D., and Molle, G. (2005). Southern European grazing lands: Production, environmental and landscape management aspects. Livest. Prod. Sci 96, 51-59. doi: https://doi.org/10.1016/j.livprodsci.2005.05.016

Hoffman, I. (2013). Adaptation to climate change: exploring the potential of locally adapted breeds. Animal 7, 346-362. doi: https://doi.org/10.1017/ s1751731113000815

INRA (2007). Alimentation des bovins, ovins et caprins. Besoins des animaux. Valeurs des aliments. Tables INRA.

Jouven, M., Lapeyronie, P., Moulin, C. H., and Bocquier, F. (2010). Rangeland utilization in Mediterranean farming systems. Animal 4, 1746-1757. doi: https: //doi.org/10.1017/S1751731110000996

Kaufmann, J. C. (2011). L'entretien compréhensif L'enquête et ses méthodes (Paris: Armand Colin), 3 edition.

Konig, E. Z., Mirkena, T., Strandberg, E., Audho, J., Ojango, J., Malmfors, B., Okeyo, A. M., and Philipsson, J. (2015). Participatory definition of breeding objectives for sheep breeds under pastoral systems-the case of Red Maasai and Dorper sheep in Kenya. Trop Anim Health Prod 48, 9-20. doi: https: //doi.org/10.1007/s11250-015-0911-7 
Kosgey, I. S., Rowlands, G. J., Arendonk, J. A. M. V., and Baker, R. L. (2008). Small ruminant production in smallholder and pastoral/extensive farming systems in Kenya. Small Ruminant Res 77, 11-24. doi: https: //doi.org/10.1016/j.smallrumres.2008.02.005

Labatut, J. (2009). Gérer des biens communs : processus de conception et régimes de coopération dans la gestion des ressources génétiques animales. Ph.D. thesis, Ecole Nationale Supérieure des Mines de Paris, Paris. (in French).

Lauvie, A., Paoli, J. C., and Moulin, C. H. (2015). Managing local breeds: a dynamic connected to livestock farming systems that concerns different levels of organization. Animal Genetic Resources 56, 119-125. doi: https://doi.org/10.1017/s2078633614000502

Leroy, G., Baumung, R., Boettcher, P., Scherf, B., and Hoffman, I. (2016a). Sustainability of crossbreeding in developing countries; definitely not like crossing a meadow. Animal 10, 262-273. doi: https://doi.org/ 10.1017/S175173111500213X

Leroy, G., Boettcher, P., Hoffmann, I., Mottet, A., Teillard, F., and Baumung, R. (2016b). An exploratory analysis on how geographic, socioeconomic, and environmental drivers affect the diversity of livestock breeds worldwide. J. Anim. Sci 94, 5055-5063. doi: https://doi.org/10.2527/jas.2016-0813

Loukovitis, D., Siasiou, A., Mitsopoulos, I., Lymberopoulos, A. G., Laga, V., and Chatziplis, D. (2016). Genetic diversity of Greek sheep breeds and transhumant populations utilizing microsatellite markers. Small Ruminant Res 136, 238-242. doi: https://doi.org/10.1016/ j.smallrumres.2016.02.008

Lozano-Jaramillo, L. M., Bastiaansen, J. W. M., Dessie, T., and Komen, H. (2018). Use of geographic information system tools to predict animal breed suitability for different agro-ecological zones. Animal 1(8). doi: https://doi.org/10.1017/S1751731118003002

MacDonald, D., Crabtree, J. R., Wiesinger, G., Dax, T., Stamou, N., Fleury, P., Lazpita, J. G., and Gibon, A. (2000). Agricultural abandonment in mountain areas of Europe: Environmental consequences and policy response. J Environ Manage 59, 47-69. doi: https: //doi.org/10.1006/jema.1999.0335

Marshall, K. (2014). Optimizing the use of breed types in developing country livestock production systems: a neglected research area. J. Anim. Breed. Genet 131, 329-340. doi: https://doi.org/10.1111/jbg.12080

Meuret, M. and Provenza, F. D. (2014). How French shepherds create meal sequences to stimulate intake and optimise use of forage diversity on rangeland. Anim Prod Sci 55. doi: https://doi.org/10.1071/ an14415

Moulin, C. H., Ingrand, S., Lasseur, J., Malderieux, S., Napoleone, M., Pluvinage, J., and Thénard, V. (2008). Comprendre et analyser les changements d'organisation et de conduite de l'élevage dans un ensemble d'exploitations: propositions méthodologiques. In L'élevage En Mouvement. Flexibilité et Adaptation Des Exploitations d'herbivores, volume Update Sciences et Technologies, Editions Quae, Versailles, 181-196. (in French).

Moulin, C. H., Pluvinage, J., and Bocquier, F. (2004). Les relations entre agrandissement des troupeaux et changements de conduite : exemple des élevages d'ovins allaitants en Crau. In Rencontres Autour Des Recherches Sur Les Ruminants, 145-148. (in French).

National Rural Network (2019). RDP actions for the conservation of endangered local breeds. In 11th Zootechnia, Thessaloniki. (in Greek).

Paoli, J. C., Viollet, A., Santucci, P., Gambotti, J. Y., and Lauvie, A. (2014). Towards a better understanding of adaptation of local breeds to livestock farming systems: an exploratory methodological proposal. In Chentouf, M., López-Francos, A., Bengoumi, M., and Gabiña, D., Technology creation and transfer in small ruminants: roles of research, development services and farmer associations., volume 108 of Options Méditerranéennes : Série A. Séminaires Méditerranéens, CIHEAM / INRAM / FAO, Zaragoza, 501-505.

Perucho, L. (2018). Rôle des pratiques de gestion génétique dans l'adéquation entre troupeaux de races locales et conduites pastorales. Ph.D. thesis, Montpellier SupAgro, Montpellier, France.

Perucho, L., Bazin, G., and Goussios, D. (2015). Crise économique grecque et nouvelles dynamiques agraires : l'exemple de la Thessalie orientale. Annales de géographie (705), 473-497. doi: https://doi.org/ 10.3917/ag.705.0473

Perucho, L., Hadjigeorgiou, I., Lauvie, A., Moulin, C. H., Paoli, J. C., and Ligda, C. (2018). Challenges for local breed management in Mediterranean dairy sheep farming: insights from Central Greece. Trop Anim Health Prod 51, 329-338. doi: https://doi.org/10. 1007/s11250-018-1688-2

Perucho, L., Ligda, C., Paoli, J. C., Hadjigeorgiou, I., Moulin, C. H., and Lauvie, A. (2019). Links between traits of interest and breeding practices: Several pathways for farmers' decision-making processes. Livest. Sci 158-165. doi: https://doi.org/10.1016/j. livsci.2018.12.017

Perucho, L., Paoli, J. C., Ligda, C., Moulin, C. H., Hadjigeorgiou, I., and Lauvie, A. (2020). Diversity of breeding practices is linked to the use of collective tools for the genetic management of the Corsican sheep breed. Italian Journal of Animal Science 19, 158-172. doi: https://doi.org/10.1080/ 1828051x.2020.1713027

Plieninger, T., Hochtl, F., and Spek, T. (2006). Traditional land-use and nature conservation in European rural landscapes. Environ Sci Policy 9, 317-321. doi: https://doi.org/10.1016/j.envsci.2006.03.001

Porqueddu, C., Melis, R. A. M., Franca, A., Sanna, F., Hadjigeorgiou, I., and Pueyo, I. C. (2017). The role of grasslands in the less favoured areas of Mediterranean Europe, in: Grassland Resources for Extensive Farming Systems in Marginal Lands: Major Drivers and Future Scenarios. In Proceedings of 19th Symposium of the European Grassland Federation, 3-22. 
Rosa-García, R., Celaya, R., García, U., and Osoro, K. (2012). Goat grazing, its interactions with other herbivores and biodiversity conservation issues. Small Ruminant Res 107(2-3), 49-64. doi: https://doi.org/ 10.1016/j.smallrumres.2012.03.021

Roschinsky, R., Kluszczynska, M., Sölkner, J., Puskur, R., and Wurzinger, M. (2015). Smallholder experiences with dairy cattle crossbreeding in the tropics: from introduction to impact. Animal 9, 150-157. doi: https: //doi.org/10.1017/s1751731114002079

Samdup, T., Udo, H. M. J., Eilers, C. H. A. M., Ibrahim, M. N. M., and Zijpp, A. J. V. D. (2010). Crossbreeding and intensification of smallholder crop-cattle farming systems in Bhutan. Livest. Sci 132, 126-134. doi: https://doi.org/10.1016/j.livsci.2010.05.014

Santucci, P. (2010). Vous avez dit pastoral ? Analyse de la mutation du pastoralisme corse.

Schnabel, S., Gutierrez, A. G., and Contador, J. F. L. (2009). Grazing and soil erosion in dehesas of SW Spain. In A., R. D., F., B. S., F., A. S., and F., L. B., Advances in Studies on Desertification, 725-728.

Sivignon, M. (1975). La Thessalie: analyse géographique d'une province grecque (Lyon: Institut des Etudes Rhodaniennes).

Stefanakis, A., Volanis, M., Zoiopoulos, P., and Hadjigeorgiou, I. (2007). Assessing the potential benefits of technical intervention in evolving the semiintensive dairy-sheep farms in Crete. Small Ruminant Res 72(1), 66-72. doi: https://doi.org/10.1016/ j.smallrumres.2006.08.006

Sternberg, M., Gutman, M., Perevolotsky, A., Ungar, E. D., and Kigel, J. (2000). Vegetation response to grazing management in a Mediterranean herbaceous community: A functional group approach. J. Appl. Ecol 37, 224-237. doi: https://doi.org/10.1046/j.13652664.2000.00491.x

Tamou, C., Boer, I. J. M. D., Ripoll-Bosch, R., and Oosting, S. (2018). Understanding roles and functions of cattle breeds for pastoralists in Benin. Livest. Sci 210, 129-136. doi: https://doi.org/10.1016/j.livsci. 2018.02.013

Tchakerian, E. (2008). Pastoralisme méditerranéen: état des lieux et perspectives pour huit régions méditerranéennes. Forêt méditerranéenne 29, 309320. (in French).

Tzanopoulos, J., Kallimanis, A. S., Bella, I., Labrianidis, L., Sgardelis, S., and Pantis, J. D. (2011). Agricultural decline and sustainable development in mountain areas in Greece : sustainability assessment of future scenarios. Land Use Policy 585-593. doi: https://doi. org/10.1016/j.landusepol.2010.11.007

Volanis, M., Stefanakis, A., Hadjigeorgiou, I., and Zoiopoulos, P. (2007). Supporting the extensive dairy sheep smallholders of the semi-arid region of Crete through technical intervention. Trop Anim Health Prod 39(5), 325-334. doi: https://doi.org/10.1007/ s11250-007-9019-z 